\title{
Original
}

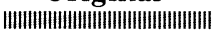

\section{Obtaining Induced Mutations of Drought Tolerance in Sorghum}

\author{
Soeranto Hoeman, Tomoko M. NAKAnISHI* and Mirzan T. RazZAK \\ Center for Application of Isotopes and Radiation, National Atomic Energy Agency \\ Batan, Indonesia \\ * Graduate School of Agricultural and Life Sciences, The University of Tokyo \\ 1-1-1 Yayoi, Bunkyo-ku, Tokyo 113-8657, Japan
}

Received August 9, 2002

\begin{abstract}
Since sorghum plant (Sorghum bicolor L.) has a big potential to be cultivated in Indonesia especially in drought-prone areas, improvement of sorghum had been carried out through mutation breeding methods. The seeds of the sorghum plant was irradiated by gamma rays emitted from cobalt-60 source. The total dose was $0.4 \mathrm{kGy}$. Through selection process in the M2 generation, a number of promising mutant lines of sorghum have been obtained and registered in the M3 generation. In the M4, a number of 100 mutant lines were tested against drought in Gunung Kidul District during the dry season in 2000 . Results of the test showed that mutant line DU/20/Psj/1, DU/20/Psj/4, DU/20/Psj/24, JA/30/Cty/21, ET/40/Psj/4 and DU/20/Psj/10 had relatively high grain yield compared to the control variety.
\end{abstract}

Key Words : sorghum, mutation breeding, radiation breeding, drought tolerance

\section{Introduction}

Gunung Kidul District of Yogyakarta Province is one of the well-known regions in Indonesia that are prone to drought year after year. But in this region, agricultural productions (crops and animals) are entirely dependent on the rain. Therefore, introduction of crops indicating high water efficiency and yield is very important for this region. A sorghum plant (Sorghum bicolor L. ) has long known by farmers in the region but its improvement and development seem to be neglected if compared with those of the other food crops.

Sorghum's potential is primarily due to its high production, low-input crop (required less fertilizer), more tolerant to drought and other adverse conditions, and its high nutrition values. In many countries, sorghum has been used as either food, feed, or industrial crops. As a food crop, sorghum has high nutrition values. Unfortunately, sorghum has so far been grown very limited by Indonesian farmers who are used to grow rice in their lands. This limitation may be due to some problems such as availability of qualified seeds of sorghum varieties.

From agronomic point of view, the local variety has some disadvantages as its characters of having high stature, late maturity, uninteresting seed color (brown), dropped head, and low production. For being used directly as food or in a food industry, white sorghum with low stature are usually more preferable.

Some improved sorghum mutant lines as results of breeding by using mutation techniques have been produced, released and listed as new varieties ${ }^{1), 2)}$. Such results have also gained from sorghum mutation breeding 
Table 1 Average of rainfall during the last 10 years in Gunung Kidul District, Yogyakarta Province (BPP Semanu, 1999)

\begin{tabular}{|l|c|l|}
\hline \multirow{2}{*}{ Month } & \multicolumn{2}{|l|}{ Average } \\
\cline { 2 - 3 } & $\begin{array}{l}\text { Rainfall } \\
\text { (mm) }\end{array}$ & $\begin{array}{l}\text { Rain } \\
\text { days }\end{array}$ \\
\hline January & 310.3 & 18 \\
\hline February & 329.0 & 19 \\
\hline March & 280.3 & 15 \\
\hline April & 253.0 & 9 \\
\hline May & 58.6 & 3 \\
\hline June & 67.0 & 4 \\
\hline July & 38.0 & 2 \\
\hline August & 14.1 & 1 \\
\hline September & 6.1 & 1 \\
\hline October & 85.6 & 5 \\
\hline November & 112.8 & 8 \\
\hline December & 201.4 & 15 \\
\hline Total & 1.756 .2 & 100 \\
\hline
\end{tabular}

research carried out in BATAN which have identified some sorghum mutant lines. These lines need to be tested in drought prone areas such as that condition in Gunung Kidul District of Yogyakarta Province. Research objective was to search for drought-tolerant sorghum that might be possible to be grown and developed as an alternative food and feed in Gunung Kidul region.

\section{Material and Method}

Sorghum varieties Durra (DU), Jampang (JA), Amrik (AM) and mutant from Keris (ET) were used as plant materials in sorghum breeding by using mutation techniques. Seeds of DU were found from food crop research center in Bogor while JA and AM were collected from farmers in West Java. ET was a mutant selected by BATAN ${ }^{3}$, 4). The seeds were then reproduced by BATAN and used as starting plant materials in the breeding research.
Table 2 Survival rate of sorghum lines grown in drought-prone areas of Gunung Kidul, Yogyakarta Province

\begin{tabular}{|l|l|}
\hline Sorghum Lines & $\begin{array}{l}\text { Survival rate } \\
(\mathbf{\%})\end{array}$ \\
\hline $\mathrm{AM} / 20 / \mathrm{Cty} / 2$ & 21.62 \\
\hline $\mathrm{AM} / 20 / \mathrm{Cty} / 4$ & 51.35 \\
\hline AM/20/Cty/9 & 47.30 \\
\hline AM CONTROL & 45.95 \\
\hline ET/40/Psj/4 & 29.73 \\
\hline ET CONTROL & 2.70 \\
\hline $\mathrm{JA} / 30 / \mathrm{Cty} / 21$ & 18.92 \\
\hline $\mathrm{JA} / 30 / \mathrm{Cty} / 34$ & 16.22 \\
\hline $\mathrm{JA} / 30 / \mathrm{Cty} / 37$ & 35.14 \\
\hline $\mathrm{JA}$ CONTROL & 24.33 \\
\hline DU/20/Psj/1 & 64.86 \\
\hline DU/30/Psj/4 & 37.84 \\
\hline DU/30/Psj/10 & 56.76 \\
\hline DU/20/Psj/11 & 64.86 \\
\hline DU/20/Psj/24 & 35.14 \\
\hline DU CONTROL & 35.14 \\
\hline
\end{tabular}

Sorghum seeds containing about $13 \%$ of water were irradiated by gamma rays emitted from ${ }^{60} \mathrm{Co}$ source. Gamma irradiator was available at the Center for Research and Development of Isotope and Radiation Technology, National Nuclear Energy Agency. The total dose was $0.4 \mathrm{kGy}$, which was found to provide the highest induced variation for plant height and harvest index, according to our previous study ${ }^{3), 4)}$.

Sorghum is self-pollinated crop so that all the M 1 plants (the first generation after gamma irradiation treatment) were harvested individually and then each plant was grown as single seed base in the M2. Plant selections were started in the M 2 generation for those having agronomic characters phenotypically significant different from the control plants. These characters included plant height, plant age, 
Table 3 Agronomic data of selected sorghum lines grown in drought-prone areas of Gunung Kidul, Yogyakarta Province

\begin{tabular}{|l|l|l|l|c|l|l|l|}
\hline \multirow{2}{*}{ Sorghum Lines } & Plant Height (cm) & \multicolumn{2}{|l|}{ No. of Leaves } & Seed Size & \multicolumn{2}{|l}{ Seed Color } & \multirow{2}{*}{ Seed Form } \\
\cline { 2 - 8 } AM/20/Cty/2 & 206.80 & 21.06 & 9.4 & 0.89 & Medium & Yellow to gray & Oval \\
\hline AM/20/Cty/4 & 224.80 & 23.08 & 9.2 & 0.84 & Small & Yellow & Oval \\
\hline AM/20/Cty/9 & 186.00 & 21.62 & 8.6 & 0.89 & Small & Yellow to gray & Oval \\
\hline ET/40/Psj/4 & 176.60 & 14.50 & 10.4 & 0.55 & Big & White & Rough round \\
\hline JA/30/Cty/21 & 95.00 & 17.32 & 4.2 & 0.45 & Small & Black & Oval \\
\hline JA/30/Cty/34 & 79.60 & 0.89 & 4.4 & 0.55 & Small & Grey to black & Oval \\
\hline JA/30/Cty/37 & 82.00 & 10.37 & 5.0 & 1.00 & Small & Yellow to Black & Oval \\
\hline DU/20/Psj/1 & 132.00 & 5.70 & 7.2 & 0.45 & Big & White to gray & Round \\
\hline DU/30/Psj/4 & 130.00 & 6.12 & 6.6 & 0.55 & Medium & White to yellow & Round \\
\hline DU/30/Psj/10 & 98.40 & 6.88 & 6.2 & 0.45 & Big & White to gray & Round \\
\hline DU/20/Psj/11 & 130.80 & 4.21 & 6.4 & 0.55 & Big & White to yellow & Round \\
\hline DU/20/Psj/24 & 129.00 & 6.52 & 6.4 & 0.55 & Big & White & Round \\
\hline DU CONTROL & 127.80 & 9.31 & 7.0 & 1.00 & Medium & Grey & Round \\
\hline
\end{tabular}

head size, seed color and yield. Dwarf or semidwarf, early maturing, big and condense head, and high yield were those among desirable agronomic characters for sorghum. Selected plants (mutant lines) were then grown in subsequent generations (M 3) for mutation identification and further selections.

Screening the promising mutant lines in the M 4 was carried out for their tolerance to drought. For this, field experiment was conducted in drought-prone areas of Gunung Kidul District, Yogyakarta Province during the dry season of 2000 . Sowing the seeds were done by the end of raining season and the sowing date was 10 June, 2000 . There was no rain at all during this sowing season and the drought condition at the time could be classified as severe drought. Average of rainfall during the last 10 years in this District was shown in Table 1. Artificial irrigation, however, was given daily only up to 20 days after sowing the seeds, just to stimulate seed germination and seedling growth.

Agronomic observations were done at reproductive growth stage for survival rate, plant height and number of leaves. Evaluation on quality traits included seed size, seed color, seed form, and nutritive contents i.e. carbohydrate, protein, fat, ash, and water contents. Analysis of the nutritive contents was performed according to the standard method reported by Apriyantono et al. with two replications for each lines. Estimated yields were calculated by seed weight of individual 
Table 4 Nutrition contents of sorghum lines grown in drought-prone areas of Gunung Kidul, Yogyakarta Province

\begin{tabular}{|c|c|c|c|c|c|}
\hline & \multicolumn{5}{|c|}{ Contents (\%) } \\
\cline { 2 - 6 } Sorghum Lines & Fat & Water & Ash. & Protein & Carbohyd \\
\hline AM/20/Cty/2 & 1.22 & 9.45 & 0.76 & 6.20 & 79.32 \\
\hline AM/20/Cty/9 & 0.82 & 10.44 & 1.22 & 6.22 & 80.50 \\
\hline AM/20/Cty/4 & 1.47 & 10.44 & 0.59 & 6.58 & 80.92 \\
\hline ET/40/Psj/4 & 1.51 & 11.27 & 1.05 & 7.95 & 81.07 \\
\hline JA/30/Cty/21 & 1.25 & 9.85 & 0.82 & 6.46 & 81.59 \\
\hline JA/30/Cty/34 & 0.96 & 9.16 & 1.86 & 6.00 & 82.01 \\
\hline JA/30/Cty/37 & 0.66 & 9.17 & 0.44 & 6.23 & 80.55 \\
\hline DU/20/Psj/1 & 0.44 & 11.10 & 0.50 & 7.39 & 80.19 \\
\hline DU/30/Psj/4 & 1.15 & 10.02 & 0.77 & 6.49 & 80.44 \\
\hline DU/30/Psj/10 & 0.71 & 10.96 & 0.94 & 8.08 & 81.30 \\
\hline DU/20/Psj/11 & 0.49 & 12.47 & 1.99 & 6.98 & 78.59 \\
\hline DU/20/Psj/24 & 1.22 & 11.70 & 0.86 & 7.80 & 81.25 \\
\hline DU CONTROL & 1.30 & 10.72 & 0.97 & 6.25 & 80.75 \\
\hline
\end{tabular}

plant basis and converted to a hectare (ton/ha). Field experiments were conducted by randomized design and test of significance between treatments used the method of orthogonal contrast. Computer program MSTAT was used in analyzing the data ${ }^{5)}$.

\section{Results and Discussion}

Gamma irradiation treatments were reported to give a significant effect on the phenotypic performance of plant height and harvest index variables in the M 2. For characters of plant height and harvest index, the dose treatment of $400 \mathrm{~Gy}$ was reported to give the highest variance $^{3), 4)}$. Following selection processes in the M 2 and M 3, a number of promising mutant lines had been registered in the M 4 . The selection was performed based on qualitative, agronomical index, such as, plant size, seed size, seed color and seed form at an experimental farm in BATAN. Then the screening in the M 4 was done for their tolerance to drought at drought-prone areas of Gunung Kidul district, Yogyakarta Province during the dry season of 2000 . Out of 100 mutant lines tested in the district, 12 promising lines were selected. These tolerant sorghum lines consisted of 3 lines of AM, 1 line of ET, 3 lines of JA, and 5 lines of DU. The survival rates for drought of these sorghums were shown in Table 2 and were registered as those having good tolerance to drought. Some lines that could not grow at all in such condition were not written in the table.

Variation in plant height and number of leaves between sorghum lines as well as 
Table 5 Estimated yield of sorghum lines grown in drought-prone areas of Gunung Kidul, Yogyakarta Province

\begin{tabular}{|c|c|c|c|c|}
\hline Sorghum Line & Tillering & Days to mature & 1000-seed weight (g) & Yield (ton/ha) \\
\hline $\mathrm{AM} / 20 / \mathrm{Cty} / 2$ & 2.5 & 105.5 & 15.432 & 2.7 \\
\hline $\mathrm{AM} / 20 / \mathrm{Cty} / 4$ & 2.5 & 99.1 & 17.518 & 2.1 \\
\hline $\mathrm{AM} / 20 / \mathrm{Cty} / 9$ & 3.3 & 103.6 & 18.355 & 2.8 \\
\hline $\mathrm{ET} / 40 / \mathrm{Psj} / 4$ & 3.6 & 98.1 & 44.462 & 4.3 \\
\hline $\mathrm{JA} / 30 / \mathrm{Cty} / 21$ & 3.3 & 90.4 & 27.105 & 3.0 \\
\hline $\mathrm{JA} / 30 / \mathrm{Cty} / 34$ & 2.0 & 87.2 & 22.764 & 2.3 \\
\hline $\mathrm{JA} / 30 / \mathrm{Cty} / 37$ & 4.1 & 92.5 & 23.147 & 2.5 \\
\hline $\mathrm{DU} / 20 / \mathrm{Psj} / 1$ & 3.0 & 85.2 & 30.874 & 3.4 \\
\hline $\mathrm{DU} / 30 / \mathrm{Psj} / 4$ & 3.6 & 86.1 & 30.056 & 4.1 \\
\hline $\mathrm{DU} / 30 / \mathrm{Psj} / 10$ & 4.1 & 87.0 & 30.964 & 3.9 \\
\hline $\mathrm{DU} / 20 / \mathrm{Psj} / 11$ & 4.3 & 86.3 & 34.870 & 3.4 \\
\hline $\mathrm{DU} / 20 / \mathrm{Psj} / 24$ & 2.5 & 86.5 & 28.166 & 3.2 \\
\hline $\mathrm{DU} \mathrm{CONTROL}$ & 2.3 & 90.4 & 26.06 & 3.0 \\
\hline
\end{tabular}

qualitative data i.e. seed size, seed color and seed form are presented in Table 3. Generally, short plants were accompanied with less leaves as shown by lines JA/30/Cty/21, JA/30/Cty/ 37 and JA/30/Cty/34. Seed size and seed color would determine quality of sorghum seeds either they were used directly as food or feed source. For being used as food source, whiteseed sorghums were usually more preferable and the seeds were usually processed into different product such as milled grain, fine flour or rough flour. From the color of the seeds, utilization of the promising lines could be directed as food source (especially for lines of DU and ET) and as feed crops (for lines of JA and AM). This effort would help the local farmers produce either alternative food or feed during the dry season in their land.

The nutrition contents of sorghum lines are presented in Table 4. The nutrition contents of some sorghum lines were found relatively high as it was shown in line $\mathrm{ET} / 40 / \mathrm{Psj} / 4$ (7.95\%), DU/20/Psj/1 (7.39\%), DU/30/Psj/10 (8.08\%), DU/20/Psj/11 (6.98\%) and DU/20/Psj/24 (7.80\%). These high-protein sorghum lines could be developed further in the region for helping overcome food crisis and human nutrition of the local inhabitants.

The short plants of JA, however, had relatively high tillering capacity (Table 5). These sorghum lines were suitable to be developed for feeding ruminant such as cow and cattle in the drought-prone region of Gunung Kidul. The plant stovers could be given to ruminant animals in form of green chop, pasture, hay or silage while the grain might be of useful to be used as a component of a poultry ransom.

Estimated economic yields(grain)of sorghum lines grown in dry conditions were presented in Table 5. Some lines had relatively high yield (more than 3 ton/ha) as it was shown by line 
JA/30/Cty/21, ET/40/Psj/4, DU/20/Psj/1, DU /20/Psj/4, DU/20/Psj/10, DU/20/Psj/11 and $\mathrm{DU} / 20 / \mathrm{Psj} / 24$. These promising lines had yield higher than the control DU variety. In reality, however, the yield might not be that high due to some constrains such as abnormal growth, disease and insect attacks etc. The other lines with low yield might also be of importance in producing biomass for supporting development of a sustainable agriculture in the area.

\section{Conclusion}

Sorghum is drought-tolerant crops. It could be grown in dry condition where other crops were not able to grow. Improvement of sorghum varieties by mutation breeding had resulted some promising mutant lines that could be developed further in Gunung Kidul District of Yogyakarta Province. Utilization of the promising lines could be directed as food source (especially for lines of DU and ET) and as feed crops (for lines of JA and AM). It is hoped that drought tolerant sorghum can help local farmers overcome food and feed crisis during dry season and also as an alternative plant in producing biomass for supporting development of a sustainable agriculture.

\section{Acknowledgments}

The work was supported and carried out under the Cooperative Research Program, Graduate School of Agricultural and Life Sciences, The University of Tokyo. We would like to express our sincere and special gratitude to Mr. K. Ikushima, Musashi Engineering, Co., who was kind enough to provide us a research funding to perform this study.

\section{References}

1) IAEA : Selection in mutation breeding. Proceedings of Consultants Meeting, Joint FAO/ IAEA, Vienna; 21-25 June 1982. STI/PUB/665. ISBN 92-0-111284-X. (1984)

2) IAEA : Manual on mutation breeding. Tech. Rep. Ser. No. 119. Sec. Ed. Joint FAO/IAEA Div. of Atomic Energy in Food and Agriculture. 287 pp. ISBN 92-0-115077-6.(1977)

3) Soeranto, H.:Pemuliaan mutasi pada sorghum (Sorghum bicolor L.) untuk perbaikan tanaman. Risalah Pertemuan Ilmiah Penelitian dan Pengembangan Aplikasi Isotop dan Radiasi, Jakarta, 18-19 Februari 1998. ISBN 979-95390-7-2 (Indonesian language) (1998)

4) Soeranto, H., Nakanishi, T. M. and Razzak, M. T. : Mutation breeding in sorghum in Indonesia, Radioisotopes, 50, 169-175 (2001)

5) Bricker, B. : User's guide to MSTAT, a software program for the design, management, and analysis of agronomic research experiments. Michigan State University (1989) 
要 旨

\section{耐乾性ソルガムの实然变異育種の試み}

H. ソラント，中西友子*，M. T. ラザック

Center for Application of Isotopes and Radiation, National Atomic Energy Agency

Batan, Indonesia

* 東京大学大学院農学生命科学研究科

113-8657 東京都文京区弥生 1-1-1

インドネシアにおける乾燥地の食料不足ならびに米の代替品としての穀物品種を確保する目的の ため, インドネシアでソルガム (Sorghum bicolor L.) の突然変異育種を行った。コバルトー60から の $\gamma$ 線を $0.4 \mathrm{kGy}$ 照射し，第 4 世代（M 4 ）まで育種実験を行った。M 2 と M 3 の選抜は研究所で 行い, M 4 については実際の乾燥地 Yogyakarta Province で行った。種子の色から食糧および飼料 に適する，耐乾性かつ蛋白総量が高い有望品種が得られた。 